WellBeing International

WBI Studies Repository

10-2-1986

\title{
The Case for the Use of Animals in Biomedical Research
}

Carl Cohen

The University Of Michigan

Follow this and additional works at: https://www.wellbeingintlstudiesrepository.org/moreaexp

Part of the Animal Experimentation and Research Commons, Animal Studies Commons, and the Bioethics and Medical Ethics Commons

\section{Recommended Citation}

Cohen C: The Case for the Use of Animals in Biomedical Research. New England Journal of Medicine.

1986, 315: 865-870.

This material is brought to you for free and open access by WellBeing International. It has been accepted for inclusion by an authorized administrator of the WBI Studies Repository. For more information, please contact wbisr-info@wellbeingintl.org.

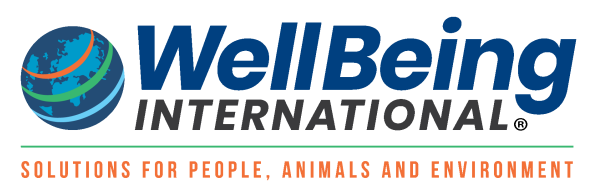


2. Norris JW, D'Alton JG. Outcome of patients with asymptomatic carotid bruits. In: Reivich M, Hurtig HI, eds. Cerebrovascular diseases. New York: Raven Press, 1983:63-71.

3. Wolf PA, Kannel WB, Sorlie P, McNamara P. Asymptomatic carotid bruit and risk of stroke: the Framingham Study. JAMA 1981; 245:1442-5.

4. Chambers BR, Norris JW. Clinical significance of asymptomatic neck bruits. Neurology (NY) 1985; 35:742-5.

5. Hennerici M, Rautenberg W, Mohr S. Stroke risk from symptomless extracranial arterial disease. Lancet 1982; 2:1180-3.

6. Dyken ML, Pokras R. The performance of endarterectomy for disease of the extracranial arteries of the head. Stroke 1984; 15:948-50.

7. Chambers BR, Norris JW. The case against surgery for asymptomatic carotid stenosis. Stroke 1984; 15:964-7.

8. Brott $T$, Thalinger $K$. The practice of carotid endarterectomy in a large metropolitan area. Stroke 1984; 15:950-5.

9. Easton JD, Sherman DG. Stroke and mortality in carotid endarterectomy: 228 consecutive operations. Stroke 1977; 8:565-8.

10. Schoenberg BS. Risk factors for cerebrovascular disease. In: Rose FC, ed Clinical neuroepidemiology. Tunbridge Wells: Pitman, 1980:151-62.

11. Wolf PA, Kannel WB, Verter J. Current status of risk factors for stroke. In Bamett HJM, ed. Symposium on cerebrovascular disease. Vol. 1. Philadelphia: WB Saunders, 1983:317-43.

12. Spencer MP, Reid JM. Cerebrovascular evaluation with the Doppler ultrasound. The Hague: Martinus Nijhoff, 1981.

13. Zwiebel WJ, Zagzebski JA, Crummy AB, Hirscher M. Correlation of peak Doppler frequency with lumen narrowing in carotid stenosis. Stroke 1982; 13:386-91.

14. D'Alton JG, Norris JW. Carotid Doppler evaluation in cerebrovascular disease. Can Med Assoc J 1983; 129:1184-9.

15. SAS user's guide. Cary, N.C.: SAS Institute, 1982.

16. Kaplan EL, Meier $P$. Nonparametric estimation from incomplete observations. J Am Stat Assoc 1958; 53:457-81.
17. Peto $R$, Pike MC, Armitage $P$, et al. Design and analysis of randomized clinical trials requiring prolonged observation of each patient. II. Analysis and examples. Br J Cancer 1977; 35:1-39.

18. Gehan EA. Statistical methods for survival time studies. In: Stoquet MJ, ed Cancer chemotherapy: prognostic factors and criteria for response. New York: Raven Press, 1975:7-35.

19. Cox DR. Regression models and life-tables. J R Stat Soc (B) 1972; 34:187220.

20. Breslow N. Covariance analysis of censored survival data. Biometrics 1974; 30:89-99.

21. Roederer GO, Langlois YE, Jager KA, et al. The natural history of carotid arterial disease in asymptomatic patients with cervical bruits. Stroke 1984; 15:605-13.

22. Canadian Cooperative Study Group. A randomized trial of aspirin and sulfinpyrazone in threatened stroke. N Engl J Med 1978; 299:539.

23. Fields WS, Lemak NA. Joint study of extracranial arterial occlusion. IX, Transient ischemic attacks in the carotid territory. JAMA 1976; 235:260810.

24. Matsumoto N, Whisnant JP, Kurland LT, Okazaki H. Natural history of stroke in Rochester Minnesota, 1955 through 1969: an extension of a previous study, 1945 through 1954. Stroke 1973; 4:20-9.

25. Thompson JE, Patman RD, Talkington CM. Asymptomatic carotid bruits: long-term outcome of patients having endarterectomy compared with unoperated controls. Ann Surg 1978; 188:308-16.

26. Braunwald $E$. Effects of coronary-artery bypass grafting on survival: implications of the randomized coronary-artery surgery study. N Engl J Med 1983: 309:1180-4

27. Myocardial infarction and mortality in the Coronary Artery Surgery Study (CASS) randomized trial. N Engl J Med 1984; 310:750-8.

28. Dyken ML. Transient ischemic attacks and aspirin, stroke and death; negative studies and Type II error. Stroke 1983; 14:2-4.

\section{SPECIAL ARTICLE}

\section{THE CASE FOR THE USE OF ANIMALS IN BIOMEDICAL RESEARCH}

\section{Carl Cohen}

$\mathrm{U}$ SING animals as research subjects in medical investigations is widely condemned on two grounds: first, because it wrongly violates the rights of animals, ${ }^{1}$ and second, because it wrongly imposes on sentient creatures much avoidable suffering. ${ }^{2}$ Neither of these arguments is sound. The first relies on a mistaken understanding of rights; the second relies on a mistaken calculation of consequences. Both deserve definitive dismissal.

\section{Why Animals Have No Rights}

A right, properly understood, is a claim, or potential claim, that one party may exercise against another. The target against whom such a claim may be registered can be a single person, a group, a community, or (perhaps) all humankind. The content of rights claims also varies greatly: repayment of loans, nondiscrimination by employers, noninterference by the state, and so on. To comprehend any genuine right fully, therefore, we must know who holds the right, against whom it is held, and to what it is a right.

From the Department of Philosophy of the University of Michigan and the University of Michigan Medical School, Ann Arbor. Address reprint requests to Professor Cohen at the Office of the Dean, University of Michigan Medical School, M7300 Medical Science Building I, Ann Arbor, MI 48109.
Alternative sources of rights add complexity. Some rights are grounded in constitution and law (e.g., the right of an accused to trial by jury); some rights are moral but give no legal claims (e.g., my right to your keeping the promise you gave me); and some rights (e.g., against theft or assault) are rooted both in morals and in law.

The differing targets, contents, and sources of rights, and their inevitable conflict, together weave a tangled web. Notwithstanding all such complications, this much is clear about rights in general: they are in every case claims, or potential claims, within a community of moral agents. Rights arise, and can be intelligibly defended, only among beings who actually do, or can, make moral claims against one another. Whatever else rights may be, therefore, they are necessarily human; their possessors are persons, human beings.

The attributes of human beings from which this moral capability arises have been described variously by philosophers, both ancient and modern: the inner consciousness of a free will (Saint Augustine ${ }^{3}$ ); the grasp, by human reason, of the binding character of moral law (Saint Thomas ${ }^{4}$ ); the self-conscious participation of human beings in an objective ethical order $\left(\mathrm{Hegel}^{5}\right)$; human membership in an organic moral community $\left(\right.$ Bradley $\left.^{6}\right)$; the development of the hu- 
man self through the consciousness of other moral selves $\left(\mathrm{Mead}^{7}\right)$; and the underivative, intuitive cognition of the rightness of an action (Prichard ${ }^{8}$ ). Most influential has been Immanuel Kant's emphasis on the universal human possession of a uniquely moral will and the autonomy its use entails. ${ }^{9}$ Humans confront choices that are purely moral; humans - but certainly not dogs or mice - lay down moral laws, for others and for themselves. Human beings are selflegislative, morally auto-nomous.

Animals (that is, nonhuman animals, the ordinary sense of that word) lack this capacity for free moral judgment. They are not beings of a kind capable of exercising or responding to moral claims. Animals therefore have no rights, and they can have none. This is the core of the argument about the alleged rights of animals. The holders of rights must have the capacity to comprehend rules of duty, governing all including themselves. In applying such rules, the holders of rights must recognize possible conflicts between what is in their own interest and what is just. Only in a community of beings capable of self-restricting moral judgments can the concept of a right be correctly invoked.

Humans have such moral capacities. They are in this sense self-legislative, are members of communities governed by moral rules, and do possess rights. Animals do not have such moral capacities. They are not morally self-legislative, cannot possibly be members of a truly moral community, and therefore cannot possess rights. In conducting research on animal subjects, therefore, we do not violate their rights, because they have none to violate.

To animate life, even in its simplest forms, we give a certain natural reverence. But the possession of rights presupposes a moral status not attained by the vast majority of living things. We must not infer, therefore, that a live being has, simply in being alive, a "right" to its life. The assertion that all animals, only because they are alive and have interests, also possess the "right to life" 10 is an abuse of that phrase, and wholly without warrant.

It does not follow from this, however, that we are morally free to do anything we please to animals. Certainly not. In our dealings with animals, as in our dealings with other human beings, we have obligations that do not arise from claims against us based on rights. Rights entail obligations, but many of the things one ought to do are in no way tied to another's entitlement. Rights and obligations are not reciprocals of one another, and it is a serious mistake to suppose that they are.

Illustrations are helpful. Obligations may arise from internal commitments made: physicians have obligations to their patients not grounded merely in their patients' rights. Teachers have such obligations to their students, shepherds to their dogs, and cowboys to their horses. Obligations may arise from differences of status: adults owe special care when playing with young children, and children owe special care when playing with young pets. Obligations may arise from special relationships: the payment of my son's college tuition is something to which he may have no right, although it may be my obligation to bear the burden if I reasonably can; my dog has no right to daily exercise and veterinary care, but I do have the obligation to provide these things for her. Obligations may arise from particular acts or circumstances: one may be obliged to another for a special kindness done, or obliged to put an animal out of its misery in view of its condition - although neither the human benefactor nor the dying animal may have had a claim of right.

Plainly, the grounds of our obligations to humans and to animals are manifold and cannot be formulated simply. Some hold that there is a general obligation to do no gratuitous harm to sentient creatures (the principle of nonmaleficence); some hold that there is a general obligation to do good to sentient creatures when that is reasonably within one's power (the principle of beneficence). In our dealings with animals, few will deny that we are at least obliged to act humanely - that is, to treat them with the decency and concern that we owe, as sensitive human beings, to other sentient creatures. To treat animals humanely, however, is not to treat them as humans or as the holders of rights.

A common objection, which deserves a response, may be paraphrased as follows:

If having rights requires being able to make moral claims, to grasp and apply moral laws, then many humans - the brain-damaged the comatose, the senile - who plainly lack those capacities must be without rights. But that is absurd. This proves [the critic concludes] that rights do not depend on the presence of moral capacities. ${ }^{1,10}$

This objection fails; it mistakenly treats an essential feature of humanity as though it were a screen for sorting humans. The capacity for moral judgment that distinguishes humans from animals is not a test to be administered to human beings one by one. Persons who are unable, because of some disability, to perform the full moral functions natural to human beings are certainly not for that reason ejected from the moral community. The issue is one of kind. Humans are of such a kind that they may be the subject of experiments only with their voluntary consent. The choices they make freely must be respected. Animals are of such a kind that it is impossible for them, in principle, to give or withhold voluntary consent or to make a moral choice. What humans retain when disabled, animals have never had.

A second objection, also often made, may be paraphrased as follows:

Capacities will not succeed in distinguishing humans from the other animals. Animals also reason; animals also communicate with one another; animals also care passionately for their young; animals also exhibit desires and preferences. ${ }^{11,12}$ Features of moral relevance rationality, interdependence, and love - are not exhibited uniquely by human beings. Therefore [this critic concludes], there can be no solid moral distinction between humans and other animals. ${ }^{10}$

This criticism misses the central point. It is not the ability to communicate or to reason, or dependence on 
one another, or care for the young, or the exhibition of preference, or any such behavior that marks the critical divide. Analogies between human families and those of monkeys, or between human communities and those of wolves, and the like, are entirely beside the point. Patterns of conduct are not at issue. Animals do indeed exhibit remarkable behavior at times. Conditioning, fear, instinct, and intelligence all contribute to species survival. Membership in a community of moral agents nevertheless remains impossible for them. Actors subject to moral judgment must be capable of grasping the generality of an ethical premise in a practical syllogism. Humans act immorally often enough, but only they - never wolves or monkeys - can discern, by applying some moral rule to the facts of a case, that a given act ought or ought not to be performed. The moral restraints imposed by humans on themselves are thus highly abstract and are often in conflict with the self-interest of the agent. Communal behavior among animals, even when most intelligent and most endearing, does not approach autonomous morality in this fundamental sense.

Genuinely moral acts have an internal as well as an external dimension. Thus, in law, an act can be criminal only when the guilty deed, the actus reus, is done with a guilty mind, mens rea. No animal can ever commit a crime; bringing animals to criminal trial is the mark of primitive ignorance. The claims of moral right are similarly inapplicable to them. Does a lion have a right to eat a baby zebra? Does a baby zebra have a right not to be eaten? Such questions, mistakenly invoking the concept of right where it does not belong, do not make good sense. Those who condemn biomedical research because it violates "animal rights" commit the same blunder.

\section{IN DEFENSE OF "SPECIESISM"}

Abandoning reliance on animal rights, some critics resort instead to animal sentience - their feelings of pain and distress. We ought to desist from the imposition of pain insofar as we can. Since all or nearly all experimentation on animals does impose pain and could be readily forgone, say these critics, it should be stopped. The ends sought may be worthy, but those ends do not justify imposing agonies on humans, and by animals the agonies are felt no less. The laboratory use of animals (these critics conclude) must therefore be ended - or at least very sharply curtailed.

Argument of this variety is essentially utilitarian, often expressly so ${ }^{13}$; it is based on the calculation of the net product, in pains and pleasures, resulting from experiments on animals. Jeremy Bentham, comparing horses and dogs with other sentient creatures, is thus commonly quoted: "The question is not, Can they reason? nor Can they talk? but, Can they suffer?" 14

Animals certainly can suffer and surely ought not to be made to suffer needlessly. But in inferring, from these uncontroversial premises, that biomedical research causing animal distress is largely (or wholly) wrong, the critic commits two serious errors.
The first error is the assumption, often explicitly defended, that all sentient animals have equal moral standing. Between a dog and a human being, according to this view, there is no moral difference; hence the pains suffered by dogs must be weighed no differently from the pains suffered by humans. To deny such equality, according to this critic, is to give unjust preference to one species over another; it is "speciesism." The most influential statement of this moral equality of species was made by Peter Singer:

The racist violates the principle of equality by giving greater weight to the interests of members of his own race when there is a clash between their interests and the interests of those of another race. The sexist violates the principle of equality by favoring the interests of his own sex. Similarly the speciesist allows the interests of his own species to override the greater interests of members of other species. The pattern is identical in each case. ${ }^{2}$

This argument is worse than unsound; it is atrocious. It draws an offensive moral conclusion from a deliberately devised verbal parallelism that is utterly specious. Racism has no rational ground whatever. Differing degrees of respect or concern for humans for no other reason than that they are members of different races is an injustice totally without foundation in the nature of the races themselves. Racists, even if acting on the basis of mistaken factual beliefs, do grave moral wrong precisely because there is no morally relevant distinction among the races. The supposition of such differences has led to outright horror. The same is true of the sexes, neither sex being entitled by right to greater respect or concern than the other. No dispute here.

Between species of animate life, however - between (for example) humans on the one hand and cats or rats on the other - the morally relevant differences are enormous, and almost universally appreciated. Humans engage in moral reflection; humans are morally autonomous; humans are members of moral communities, recognizing just claims against their own interest. Human beings do have rights; theirs is a moral status very different from that of cats or rats.

I am a speciesist. Speciesism is not merely plausible; it is essential for right conduct, because those who will not make the morally relevant distinctions among species are almost certain, in consequence, to misapprehend their true obligations. The analogy between speciesism and racism is insidious. Every sensitive moral judgment requires that the differing natures of the beings to whom obligations are owed be considered. If all forms of animate life - or vertebrate animal life? - must be treated equally, and if therefore in evaluating a research program the pains of a rodent count equally with the pains of a human, we are forced to conclude (1) that neither humans nor rodents possess rights, or (2) that rodents possess all the rights that humans possess. Both alternatives are absurd. Yet one or the other must be swallowed if the moral equality of all species is to be defended.

Humans owe to other humans a degree of moral regard that cannot be owed to animals. Some humans take on the obligation to support and heal others, both 
humans and animals, as a principal duty in their lives; the fulfillment of that duty may require the sacrifice of many animals. If biomedical investigators abandon the effective pursuit of their professional objectives because they are convinced that they may not do to animals what the service of humans requires, they will fail, objectively, to do their duty. Refusing to recognize the moral differences among species is a sure path to calamity. (The largest animal rights group in the country is People for the Ethical Treatment of Animals; its codirector, Ingrid Newkirk, calls research using animal subjects "fascism" and "supremacism." "Animal liberationists do not separate out the human animal," she says, "so there is no rational basis for saying that a human being has special rights. A rat is a pig is a dog is a boy. They're all mammals." ${ }^{15}$ )

Those who claim to base their objection to the use of animals in biomedical research on their reckoning of the net pleasures and pains produced make a second error, equally grave. Even if it were true - as it is surely not - that the pains of all animate beings must be counted equally, a cogent utilitarian calculation requires that we weigh all the consequences of the use, and of the nonuse, of animals in laboratory research. Critics relying (however mistakenly) on animal rights may claim to ignore the beneficial results of such research, rights being trump cards to which interest and advantage must give way. But an argument that is explicitly framed in terms of interest and benefit for all over the long run must attend also to the disadvantageous consequences of not using animals in research, and to all the achievements attained and attainable only through their use. The sum of the benefits of their use is utterly beyond quantification. The elimination of horrible disease, the increase of longevity, the avoidance of great pain, the saving of lives, and the improvement of the quality of lives (for humans and for animals) achieved through research using animals is so incalculably great that the argument of these critics, systematically pursued, establishes not their conclusion but its reverse: to refrain from using animals in biomedical research is, on utilitarian grounds, morally wrong.

When balancing the pleasures and pains resulting from the use of animals in research, we must not fail to place on the scales the terrible pains that would have resulted, would be suffered now, and would long continue had animals not been used. Every disease eliminated, every vaccine developed, every method of pain relief devised, every surgical procedure invented, every prosthetic device implanted - indeed, virtually every modern medical therapy is due, in part or in whole, to experimentation using animals. Nor may we ignore, in the balancing process, the predictable gains in human (and animal) well-being that are probably achievable in the future but that will not be achieved if the decision is made now to desist from such research or to curtail it.

Medical investigators are seldom insensitive to the distress their work may cause animal subjects. Oppo- nents of research using animals are frequently insensitive to the cruelty of the results of the restrictions they would impose. ${ }^{2}$ Untold numbers of human beings real persons, although not now identifiable - would suffer grievously as the consequence of this wellmeaning but shortsighted tenderness. If the morally relevant differences between humans and animals are borne in mind, and if all relevant considerations are weighed, the calculation of long-term consequences must give overwhelming support for biomedical research using animals.

\section{Concluding Remarks}

\section{Substitution}

The humane treatment of animals requires that we desist from experimenting on them if we can accomplish the same result using alternative methods - in vitro experimentation, computer simulation, or others. Critics of some experiments using animals rightly make this point.

It would be a serious error to suppose, however, that alternative techniques could soon be used in most research now using live animal subjects. No other methods now on the horizon - or perhaps ever to be available - can fully replace the testing of a drug, a procedure, or a vaccine, in live organisms. The flood of new medical possibilities being opened by the successes of recombinant DNA technology will turn to a trickle if testing on live animals is forbidden. When initial trials entail great risks, there may be no forward movement whatever without the use of live animal subjects. In seeking knowledge that may prove critical in later clinical applications, the unavailability of animals for inquiry may spell complete stymie. In the United States, federal regulations require the testing of new drugs and other products on animals, for efficacy and safety, before human beings are exposed to them. ${ }^{16,17}$ We would not want it otherwise.

Every advance in medicine - every new drug, new operation, new therapy of any kind - must sooner or later be tried on a living being for the first time. That trial, controlled or uncontrolled, will be an experiment. The subject of that experiment, if it is not an animal, will be a human being. Prohibiting the use of live animals in biomedical research, therefore, or sharply restricting it, must result either in the blockage of much valuable research or in the replacement of animal subjects with human subjects. These are the consequences - unacceptable to most reasonable persons - of not using animals in research.

\section{Reduction}

Should we not at least reduce the use of animals in biomedical research? No, we should increase it, to avoid when feasible the use of humans as experimental subjects. Medical investigations putting human subjects at some risk are numerous and greatly varied. The risks run in such experiments are usually unavoidable, and (thanks to earlier experiments on ani- 
mals) most such risks are minimal or moderate. But some experimental risks are substantial.

When an experimental protocol that entails substantial risk to humans comes before an institutional review board, what response is appropriate? The investigation, we may suppose, is promising and deserves support, so long as its human subjects are protected against unnecessary dangers. May not the investigators be fairly asked, Have you done all that you can to eliminate risk to humans by the extensive testing of that drug, that procedure, or that device on animals? To achieve maximal saf ety for humans we are right to require thorough experimentation on animal subjects before humans are involved.

Opportunities to increase human safety in this way are commonly missed; trials in which risks may be shifted from humans to animals are often not devised, sometimes not even considered. Why? For the investigator, the use of animals as subjects is of ten more expensive, in money and time, than the use of human subjects. Access to suitable human subjects is often quick and convenient, whereas access to appropriate animal subjects may be awkward, costly, and burdened with red tape. Physician-investigators have often had more experience working with human beings and know precisely where the needed pool of subjects is to be found and how they may be enlisted. Animals, and the procedures for their use, are often less familiar to these investigators. Moreover, the use of animals in place of humans is now more likely to be the target of zealous protests from without. The upshot is that humans are sometimes subjected to risks that animals could have borne, and should have borne, in their place. To maximize the protection of human subjects, I conclude, the wide and imaginative use of live animal subjects should be encouraged rather than discouraged. This enlargement in the use of animals is our obligation.

\section{Consistency}

Finally, inconsistency between the profession and the practice of many who oppose research using animals deserves comment. This frankly ad hominem observation aims chiefly to show that a coherent position rejecting the use of animals in medical research imposes costs so high as to be intolerable even to the critics themselves.

One cannot coherently object to the killing of animals in biomedical investigations while continuing to eat them. Anesthetics and thoughtful animal husbandry render the level of actual animal distress in the laboratory generally lower than that in the abattoir. So long as death and discomfort do not substantially differ in the two contexts, the consistent objector must not only refrain from all eating of animals but also protest as vehemently against others eating them as against others experimenting on them. No less vigorously must the critic object to the wearing of animal hides in coats and shoes, to employment in any industrial enterprise that uses animal parts, and to any commercial development that will cause death or distress to animals.

Killing animals to meet human needs for food, clothing, and shelter is judged entirely reasonable by most persons. The ubiquity of these uses and the virtual universality of moral support for them confront the opponent of research using animals with an inescapable difficulty. How can the many common uses of animals be judged morally worthy, while their use in scientific investigation is judged unworthy?

The number of animals used in research is but the tiniest fraction of the total used to satisfy assorted human appetites. That these appetites, often base and satisfiable in other ways, morally justify the far larger consumption of animals, whereas the quest for improved human health and understanding cannot justify the far smaller, is wholly implausible. Aside from the numbers of animals involved, the distinction in terms of worthiness of use, drawn with regard to any single animal, is not defensible. A given sheep is surely not more justifiably used to put lamb chops on the supermarket counter than to serve in testing a new contraceptive or a new prosthetic device. The needless killing of animals is wrong; if the common killing of them for our food or convenience is right, the less common but more humane uses of animals in the service of medical science are certainly not less right.

Scrupulous vegetarianism, in matters of food, clothing, shelter, commerce, and recreation, and in all other spheres, is the only fully coherent position the critic may adopt. At great human cost, the lives of fish and crustaceans must also be protected, with equal vigor, if speciesism has been forsworn. A very few consistent critics adopt this position. It is the reductio ad absurdum of the rejection of moral distinctions between animals and human beings.

Opposition to the use of animals in research is based on arguments of two different kinds - those relying on the alleged rights of animals and those relying on the consequences for animals. I have argued that arguments of both kinds must fail. We surely do have obligations to animals, but they have, and can have, no rights against us on which research can infringe. In calculating the consequences of animal research, we must weigh all the long-term benefits of the results achieved - to animals and to humans - and in that calculation we must not assume the moral equality of all animate species.

\section{ReFERENCES}

1. Regan $\mathrm{T}$. The case for animal rights. Berkeley, Calif.: University of California Press, 1983.

2. Singer P. Animal liberation. New York: Avon Books, 1977.

3. St. Augustine. Confessions. Book Seven. 397 A.D. New York: Pocketbooks, 1957:104-26.

4. St. Thomas Aquinas. Summa theologica. 1273 A.D. Philosophic texts. New York: Oxford University Press, 1960:353-66.

5. Hegel GWF. Philosophy of right. 1821. London: Oxford University Press, 1952:105-10.

6. Bradley FH. Why should I be moral? 1876. In: Melden AI, ed. Ethical theories. New York: Prentice-Hall, 1950:345-59. 
7. Mead GH. The genesis of the self and social control. 1925. In: Reck AJ, ed. Selected writings. Indianapolis: Bobbs-Merrill, 1964:264-93.

8. Prichard HA. Does moral philosophy rest on a mistake? 1912. In: Cellars W, Hospers J, eds. Readings in ethical theory. New York: Appleton-Century-Crofts, 1952:149-63.

9. Kant I. Fundamental principles of the metaphysic of morals. 1785. New York: Liberal Arts Press, 1949.

10. Rollin BE. Animal rights and human morality. New York: Prometheus Books, 1981

11. Hoff C. Immoral and moral uses of animals. N Engl J Med 1980; 302:115-8.

12. Jamieson D. Killing persons and other beings. In: Miller HB, Williams
WH, eds. Ethics and animals. Clifton, N.J.: Humana Press, 1983:135-46.

13. Singer P. Ten years of animal liberation. New York Review of Books. 1985; 31:46-52.

14. Bentham J. Introduction to the principles of morals and legislation. London: Athlone Press, 1970.

15. McCabe K. Who will live, who will die? Washingtonian Magazine. August 1986:115.

16. U.S. Code of Federal Regulations, Title 21, Sect. 505(i). Food, drug, and cosmetic regulations.

17. U.S. Code of Federal Regulations, Title 16, Sect. 1500.40-2. Consumer product regulations.

\section{MEDICAL INTELLIGENCE}

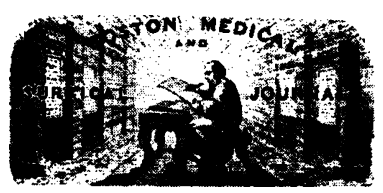

\section{CURRENT CONCEPTS}

\section{CONTROL OF ASTHMA BY AEROSOLS}

\author{
Michael T. Newhouse, M.D., \\ and Myrna B. Dolovigh, P.Eng.
}

$\mathrm{P}$ HYSICIANS have been intrigued with the idea of inhalation therapy for more than a century, since patients were advised to smoke cigarettes containing anticholinergic botanicals such as Datura stramonium to obtain relief from asthma attacks. ${ }^{1}$

The use of aerosols to treat asthma allows an almost ideal therapeutic ratio to be achieved, since minute doses of inhaled medication provide optimal maintenance therapy with minimal side effects. ${ }^{2-6}$ In severe acute asthma, sympathomimetic bronchodilator aerosols are superior to systemic therapy with the same agents. ${ }^{7,8}$ In chronic asthma, adrenoceptor-agonist aerosols provide greater and more rapid bronchodilatation and are also more effective in preventing airway responses to exercise and histamine than the oral form of the same medications. ${ }^{9-12}$ Although sympathomimetic aerosols are more effective than oral or intravenous medications, they cause much less tremor, tachycardia, palpitations, and anxiety (which are commonly experienced with the oral or intravenous therapy). ${ }^{7,13,14}$ Similarly, inhaled topically potent steroids have been shown to act effectively in the prophylactic management of moderately severe asthma, without causing the serious complications of longterm treatment with systemic steroids. ${ }^{6}$ A variety of relatively selective $\boldsymbol{\beta}_{2}$-sympathomimetic agents (albuterol, fenoterol, terbutaline, and bitolterol), anticholinergic bronchodilators (ipratropium bromide and

From the Firestone Regional Chest-Allergy Unit and the Aerosol Research Laboratory, St. Joseph's Hospital, McMaster University, Hamilton, Ont., Canada. Address reprint requests to Dr. Newhouse at St. Joseph's Hospital, 50 Charlton Ave. E., Hamilton, ON L8N 4A6, Canada. methylatropine nitrate), and antiallergic and antiinflammatory drugs (cromolyn and various steroids) are now available as aerosols and are frequently able (alone or in combination) to control all but the most severe cases of chronic asthma, without the addition of oral medication. ${ }^{3,6}$

\section{Aerosol Generation, Characteristics, and Delivery}

Therapeutic aerosols used in the treatment of reversible airflow obstruction may be produced either by metered-dose inhalers, which provide unit doses of medication from fluorocarbon-pressurized canisters or from capsules, or by continuously or intermittently generated wet aerosols from ultrasonic or jet nebulizers that contain drug solutions (which patients usually inhale by tidal breathing). Devices for intermittent positive-pressure breathing are now rarely used to deliver therapeutic aerosols except to patients with respiratory failure who need assisted ventilation.

The deposition of aerosol in the lower respiratory tract is a function of inertial impaction and sedimentation due to gravity. These processes depend in turn on the size of the aerosol ${ }^{15,16}$ and the respiratory variables - namely, inspiratory flow rate, frequency, tidal volume, breath-holding time, ${ }^{17-20}$ and airway caliber. ${ }^{16,21,22}$ Aerosol generators used for therapeutic purposes produce aerosol particles that are 0.5 to $35 \mu \mathrm{m}$ in diameter. ${ }^{23,24}$ However, only particles with aerodynamic diameters of 1 to $5 \mu \mathrm{m}$ are efficiently deposited in the lower respiratory $\operatorname{tract}^{15}$; these represent, even under optimal inhalation conditions, only 13 percent of the output from a metereddose inhaler ${ }^{17}$ and only 1 to 5 percent of that from most nebulizers. ${ }^{4,23}$ Increased inspiratory flow rates, as in patients with acute asthma, result in increased losses because of impaction of the aerosol particles in the upper airway and at the bifurcations of the first few bronchial divisions. ${ }^{19}$ When inspiratory flow rates are maintained below 1 liter per second, deposition of particles with diameters of 1 to $5 \mu \mathrm{m}$ in the pulmonary airways is increased ${ }^{17}$ and bronchodilatation is enhanced. ${ }^{25}$ Furthermore, because particles with diameters less than $5 \mu \mathrm{m}$ need up to two seconds to settle onto the walls of terminal bronchioles and much longer in central airways, ${ }^{16}$ breath-holding for about 10 seconds after inhalation of the aerosol will also result in increased deposition of the aerosol and improved 